\title{
DEVELOPMENT OF AN INTEGRATED TRANSPORT SYSTEM IN DISTRIBUTION CENTRES: A FA'WOT ANALYSIS
}

\author{
Dragan Pamučar, Goran Ćirović, Dragoljub Sekulović
}

Original scientific paper Strategic planning which focuses on transport is based fundamentally on adjusting to changes in the operational environment. Strengths, Weaknesses, Opportunities and Threats (SWOT) analysis is a commonly used tool for analyzing both the internal and external environments in order to attain a systematic approach and support for a decision-making situation. In this study, we show how some weaknesses of SWOT analysis can be avoided and how it can be elaborated upon in order to provide a more comprehensive decision support. The research was based on expert interviews, which were structured according to the principles of value-focused thinking and SWOT analysis. FA'WOT is a hybrid method combining the well known SWOT analysis and the Fuzzy Analytic Hierarchy Process (FAHP). This paper presents modification of the Saaty-s scale, in which fuzzy numbers have been used for determining weight values of criteria and alternatives. Unlike the papers describing the procedure of fuzzification of the AHP/ANP method, the method described here takes into account the level of uncertainty of the decision maker. After application of the AHP/ANP method in this way, the values of the functions criteria for each considered alternative are obtained. Certain values of the level of certainty are corresponding to the obtained values of the functions criteria. It is possible to generate various sets of the values of criterion functions. Using this procedure it is possible to identify and rank the factors affecting the functioning of a system. FAHP's connection to SWOT yields analytically determined priorities for the factors included in SWOT analysis and makes them commensurable. The aim in applying the hybrid method is to improve the quantitative information basis of strategic planning processes. The hybrid FA'WOT model is used in determining the development strategy for integrated transport in the Lafarge Beocin cement plant.

Keywords: fuzzy AHP; fuzzy logic; integrated transport; multi-criteria decision making

\section{Razvoj integriranog transportnog sustava u distributivnim centrima: FA'WOT model}

Izvorni znanstveni članak

Strateško planiranje usmjereno ka transportu zasniva se u osnovi na prilagođavanju promjenama u operativnom okruženju. Analiza prednosti, slabosti, mogućnosti i opasnosti (SWOT) najčešće je rabljen alat za analizu i unutarnje i vanjske sredine, kako bi se postigao sustavni pristup i podrška pri donošenju odluka. U ovom istraživanju pokazujemo kako se neke slabosti SWOT analize mogu izbjeći i kako se ona može razraditi da bi se osigurala sveobuhvatnija podrška odlučivanju. Istraživanje je zasnovano na ekspertnim intervjuima koji su strukturirani prema principima mišljenja usmjerenog na vrijednosti i SWOT analizu. FA'WOT je hibridna metoda u kojoj se dobro poznata SWOT analiza kombinira s fuzzy analitičkim hijerarhijskim procesom (FAHP). U radu je prikazana modifikacija Saatyjeve skale tako što su za određivanje težinskih vrijednosti kriterija i alternativa upotrebljeni fuzzy brojevi. Za razliku od radova u kojima je opisan postupak fazifikacije AHP/ANP metode opisani model uzima u obzir stupanj neizvjesnosti donositelja odluke. Na ovaj način, nakon primjene AHP/ANP metode, dobivaju se vrijednosti kriterijskih funkcija za svaku od promatranih alternativa. Dobivenim vrijednostima kriterijskih funkcija odgovara određena vrijednost stupnja uvjerenosti. Za različite vrijednosti stupnja uvjerenosti moguće je generirati različite skupove vrijednosti kriterijskih funkcija. Rabeći ovaj postupak moguće je identificirati i rangirati čimbenike koji utječu na funkcioniranje sustava. FAHP-ova veza s SWOT daje analitički utvrđene prioritete za faktore uključene u SWOT analizu i čini ih mjerljivim. Cilj u primjeni hibridne metode je poboljšati osnove kvantitativnih informacija procesa strateškog planiranja. Primjena hibridnog FA'WOT modela prikazana je za određivanje strategije razvoja integralnog transporta u tvornici Lafarge Beocin Cement.

Ključne riječi: fuzzy AHP; fuzzy logika; integrirani transport; multi-kriteriji odlučivanja

\section{Introduction}

Multiple Criteria Decision Making was introduced as a promising and important field of study in the early 1970 s. Since then, the number of contributions to theories and models, which could be used as a basis for more systematic and rational decision making with multiple criteria, has continued to grow at a steady rate. A number of surveys, cf e.g. Bana e Costa [1], show the vitality of the field and the multitude of methods which have been developed. When Bellman and Zadeh, and a few years later Zimmermann, introduced fuzzy sets into the field, they cleared the way for a new family of methods to deal with problems which had been inaccessible to and unsolvable with standard MCDM techniques [2]. Many approaches and techniques can be used to analyze strategic cases. Among them, strengths, weaknesses, opportunities, and threats (SWOT) analysis, which evaluates the strengths, weaknesses, opportunities, and threats of an organization, is the most common [3, 4] SWOT analysis is an important support tool for decisionmaking, and is commonly used as a means of systematically analyzing an organization's internal and external environment [3, 5]. Strengths and weaknesses constitute factors within the system that enable and hinder the organization with regard to achieving its goal, respectively. Opportunities and threats are considered as exogenous factors that facilitate and limit the organization in attaining its goals, respectively [6]. The strengths and weaknesses are identified by an internal environment appraisal, while the opportunities and threats are identified by an external environment appraisal [7, 8, 9]. By identifying strengths, weaknesses, opportunities, and threats, the organization can build strategies upon its strengths, eliminate its weaknesses, and exploit its opportunities or use them to counter the threats $[10,11]$.

If SWOT analysis is done correctly, this model can be a good base for strategy formulation. But it is not nondefect. This analysis lacks the possibility of comprehensively appraising the strategic decision-making situation; merely pinpointing the number of factors in strength, weakness, opportunity or threat groups does not pinpoint the most significant group. In addition, SWOT includes no means of analytically determining the importance of factors or of assessing the fit between SWOT factors and alternative decisions. Further 
utilization of SWOT is, thus, mainly based on the qualitative analysis, capabilities and expertise of the persons participating. In the planning process, as such processes are often complicated by numerous criteria and interdependencies, it may be that the utilization of SWOT is insufficient [10].

Conventional SWOT analysis cannot appraise the strategic decision-making situation comprehensively [4]. Furthermore, SWOT does not provide means of analytically determining the importance of the factors or assessing decision alternatives according to the factors [10]. The use of SWOT alone is based mainly on the qualitative analysis made in the planning process. In fact the result of a SWOT analysis is often only a listing or an incomplete qualitative examination of internal and external factors $[11,12,13]$.

Many researchers use the analytical hierarchy process (AHP) technique to quantify the SWOT analysis. Kurttila et al [11] developed a hybrid method (utilizing the analytic hierarchy process (AHP) in SWOT analysis) to eliminate the weaknesses in the measurement and evaluation steps of the SWOT analysis. Used in combination with AHP, the SWOT approach can provide a quantitative measure of the importance of each factor in decision-making. AHP enables decision makers to assign a relative priority to each factor through pairwise comparison $[12,11,14,15]$. In the SWOT-AHP method, SWOT analysis is made more analytical by giving numerical rates to the SWOT factors as well as to the four SWOT groups [3, 16]. The integrated SWOT-AHP approach is preferred as the intensities of strengths, weaknesses, opportunities, and threats can be quantified, and therefore can lead to a more realistic and effective decision than stand-alone SWOT or AHP [7, 17]. This method has been used in various fields of study $[17,18$, $19,20,21,22]$.

In this study, the SWOT-FAHP approach is used to define the strategy for developing integrated transport (IT) in the Lafarge Beocin Cement Plant (LBCP) in a hierarchical structure of factors. It evaluates factors in pairs, quantifies the relative importance of each factor to the decision, determines the priorities of the strategies, and finds out the best strategy for integrated transport. The aforementioned model is shown in the following section of the paper.

\section{$2 \quad$ FA'WOT model}

In the process of designing the organizational structure, certain decisions have to be made. It is worth pointing out that subjective evaluation of certain parameters differs from one decision-maker to another. Quite a convenient approach in quantifying these parameters is the fuzzy set theory.

Since fuzzification of the AHP method is primarily based on fuzzification of the grading scale, the following part of this paper will present a new approach to optimization of the dynamic grading scale. Fuzzification of the basic AHP method has been done in such a way that triangle fuzzy numbers have been used for determining the essential criteria values, and fuzzy arithmetic has been used for the whole procedure. Fuzzy numbers are intuitively easy to use when expressing the decision maker's qualitative assessments.

This way of defining the confidence interval does not take into account the level of uncertainty used for the evaluation of linguistic expressions. The level of uncertainty is represented by the length of the fuzzy number base. In other words, the greater the uncertainty in assessment of the linguistic expression, the bigger the length of the base (certainty interval) of the fuzzy number.

Unlike the above mentioned works, the model represented in this work takes into account the level of uncertainty, which is marked with parameter $\beta$. In this case, the greatest possible uncertainty is described by the value $\beta=0$, while the value $\beta=1$ corresponds to the situation in which we are totally sure that the linguistic expression corresponds to the given comparison of the optimality criteria. The value of the parameter $\beta$ can be any number which is within the interval $[0,1]$. In this way, the upper and lower limits of the confidence interval of the fuzzy number are chosen randomly for the given value of the parameter $\beta$, so that they are within the limits defined by the expression:

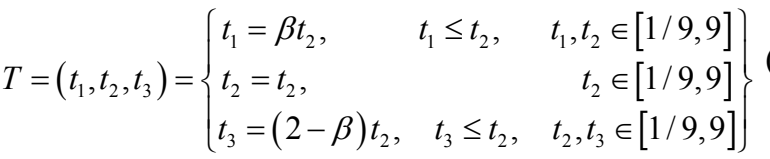

Application of the described procedure means realization of Saaty's scale of fuzzification developed by Pamucar et al [23]. In Saaty's scale, a fuzzy number $T=\left(t_{1}, t_{2}, t_{3}\right)=(x \beta, x,(2-\beta) x), x \in[1,9]$ is defined as:

$t_{1}=x \beta= \begin{cases}x \beta, & \forall 1 \leq x \beta \leq x \\ 1, & \forall x \beta<1\end{cases}$

$t_{2}=x, \forall x \in[1,9]$

$t_{3}=(2-\beta) x= \begin{cases}(2-\beta) x, & \forall x \leq(2-\beta) x \leq 9 \\ 9, & \forall(2-\beta) x>9\end{cases}$

Inversive fuzzy number

$$
T^{-1}=\left(1 / t_{1}, 1 / t_{2}, 1 / t_{3}\right)=(1 /(2-\beta) x, 1 / x, 1 / \beta x),
$$
$x \in[1 / 9,1]$ is defined as:

$$
\begin{aligned}
& 1 / t_{1}=1 /(2-\beta) x=\left\{\begin{array}{l}
1 /(2-\beta) x, \forall x<1 /(2-\beta) x<1 \\
1, \forall 1 /(2-\beta) x>1
\end{array}\right. \\
& 1 / t_{2}=1 / x, \forall 1 / x \in[1 / 9,1] \\
& 1 / t_{3}=1 / \beta x= \begin{cases}1 / \beta x, & \forall 1 / 9 \leq 1 / \beta x \leq 1 / x \\
1 / 9, & \forall 1 / \beta x<1 / 9\end{cases}
\end{aligned}
$$

In this way, the values of the criteria functions for every considered alternative are obtained after application of the AHP method. A certain value of parameter $\beta$ corresponds to the obtained values of the criteria functions. It is possible to generate various sets of values of the criteria functions for various values of parameter $\beta$. 
After defining the parameters of the fuzzified Saaty scale, the conditions are created for a description of the steps for implementing the FA'WOT model. The FA'WOT model includes the following steps:

Step 1. Identify SWOT subfactors and determine the alternative strategies according to the SWOT subfactors. Determine the importance degrees of the SWOT factors.

If the model used for evaluation of alternatives of the already proposed organizational structure alternatives, this step is omitted. The following steps will represent a general case where $K$ is considered from the point of different optimality criteria in terms of which the best alternative for a finite set of alternatives is determined $A=\left\{a_{1}, a_{2}, \ldots, a_{n}\right\},(n \geq 2)$. Optimum criteria are formally given as $K=\{1,2, \ldots, k, \ldots, K\}$, where $K$ is the overall number of the criteria considered. A multiple-attribute problem in the decision-making is represented by the matrix $F$ dimension $K \times A$.

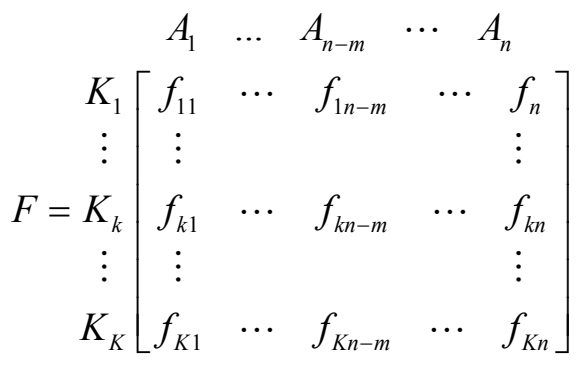

where $f_{k i}(i=\overline{1, A}, k=\overline{1, K})$ is the linguistic or numerical value of the optimum criterion $k \in K$ for alternatives $a(a \in A)$.

Step 2. The Aggregation Principle. $K=\{1,2, \ldots, k, \ldots$, $K\}$ is a set of optimality criteria, where $K$ is the overall number of the considered criteria [7]. Every criterion can be disaggregated into sub-criteria. If $k_{j}$ is the overall number of sub-criteria in the $j^{\text {th }}$ criterion, the overall number of criteria can be given as:

$$
K=\sum_{j=1}^{n} k_{j}
$$

Every criterion has to be divided into sub-criteria. In that case $k_{j}$ of the criterion equals 1 . This is important for understanding the aggregation process of judgments made at two consecutive hierarchical levels, where criteria and sub-criteria are located. Here, criteria and subcriteria are aggregated by shifting criteria at the subcriteria level. After that shift, the whole criteria level does not exist anymore.

Step 3. Evaluating Criteria. The ranking procedure starts with the determination of the importance of criteria with respect to the goal. By using a fuzzified scale, a fuzzy reciprocal judgment matrix for criteria is determined as:

$$
A=\left[\begin{array}{ccccc}
\tilde{a}_{11} & \cdots & \tilde{a}_{1 n-m} & \cdots & \tilde{a}_{M} \\
\vdots & & & & \vdots \\
a_{k 1} & \cdots & a_{k n-M} & \cdots & a_{k M} \\
\vdots & & & & \vdots \\
a_{K 1} & \cdots & a_{K n-M} & \cdots & a_{K M}
\end{array}\right]
$$

where $a_{i j}=1$ for all $i=j(i, j=1,2, \ldots, M)$ and $a_{i j}=1 / a_{j i}$.

By applying the fuzzy synthetic extent, corresponding weights of criteria can be determined as:

$w_{i}=\frac{\sum_{j=1}^{M} a_{i j}}{\sum_{k=1}^{M} \sum_{l=1}^{K} a_{k l}}, \sum_{i=1}^{K} w_{i}=1, w_{i} \in[0,1], i=1,2, \ldots M$

It should be noted that the fuzzy extent (Eq. 11) could be defined as the result of fuzzy arithmetic, or by using the extension principle. The second is slightly more difficult, but would lead to reduced uncertainty.

Step 4. Evaluating Sub-criteria. For the given criterion $C_{j}$, which splits into $k_{j}$ sub-criteria, it is necessary to determine the relative importance of the sub-criteria with respect to this criterion. After that, the fuzzy judgment matrix can be determined as:

$$
A_{j}=\left[\begin{array}{cccc}
a_{11} & a_{12} & \ldots & a_{1 k_{j}} \\
a_{21} & a_{22} & \ldots & a_{2 k_{j}} \\
\ldots & \ldots & \ldots & \ldots \\
a_{k_{j} 1} & a_{k_{j} 2} & \ldots & a_{k_{j} k_{j}}
\end{array}\right]
$$

The weights of sub-criteria with respect to given criterion are obtained again as fuzzy extents.

Final sub-criteria weights are derived through the aggregation of the weights at two consecutive levels. Multiplying sub-criteria weights by respective criterion weight (Eq. 11) gives:

$$
w_{j}^{p}=\left(\frac{\sum_{l=1}^{k_{j}} a_{i l}}{\sum_{i=1}^{k_{j}} \sum_{l=1}^{k_{j}} a_{i l}}\right) \cdot w_{j}, j=1,2, \ldots M ; p=1,2, \ldots, k_{j}
$$

where $w_{j}^{p}$ are the aggregated fuzzy weights of subcriteria. They are entries of the weight vector 13 with the total length $K$.

$W=\left(w_{1}^{1}, w_{1}^{2}, . ., w_{1}^{k 1}, w_{2}^{1}, w_{2}^{2}, . ., w_{2}^{k 2}, . ., w_{j}^{1}, w_{j}^{2}, . ., w_{j}^{k j}, . ., w_{M}^{1}, w_{M}^{2}, . ., w_{M}^{k M}\right)$

Step 5. Evaluating alternatives. The provided $N$ alternatives are pairwise compared with respect to each of the $K$ sub-criteria. After obtaining $K$ fuzzy judgment matrices of type 14 , the fuzzy extent 15 produces the decision matrix 16. 


$$
W_{k}=\left[\begin{array}{cccc}
a_{11} & a_{12} & \ldots & a_{1 N} \\
a_{21} & a_{22} & \ldots & a_{2 N} \\
\ldots & \ldots & \ldots & \ldots \\
a_{N 1} & a_{N 2} & \ldots & a_{N N}
\end{array}\right], k=1,2, \ldots, K
$$

$$
x_{i j}=\frac{\sum_{k=1}^{K} a_{i k}}{\sum_{l=1}^{N} \sum_{m=1}^{K} a_{l m}}, i=1,2, \ldots N ; j=1,2, \ldots, K
$$

$$
X=\left[\begin{array}{cccc}
x_{11} & x_{12} & \ldots & x_{1 N} \\
x_{21} & x_{22} & \ldots & x_{2 N} \\
\ldots & \ldots & \ldots & \ldots \\
x_{N 1} & x_{N 2} & \ldots & x_{N N}
\end{array}\right], k=1,2, \ldots, K
$$

In the decision matrix $X, x_{i j}$ represents the resultant fuzzy performance assessment of the alternative $A_{i} \quad(i=1$, $2, \ldots, N)$ with respect to the $j$ th sub-criterion $(j=1,2, \ldots, K)$.

Step 6. Performance matrix. As proposed by Deng [21], an overall performance of each alternative across all sub-criteria may be represented by the fuzzy performance matrix 17.

$$
Z=\left[\begin{array}{cccc}
x_{11} w_{1} & x_{12} w_{2} & \ldots & x_{1 N} w_{K} \\
x_{21} w_{1} & x_{22} w_{2} & \ldots & x_{2 N} w_{K} \\
\ldots & \ldots & \ldots & \ldots \\
x_{N 1} w_{1} & x_{N 2} w_{2} & \ldots & x_{N N} w_{K}
\end{array}\right]
$$

It is obtained by multiplying the entries of the weighting vector 13 by the related column values of the decision matrix 16 and by applying fuzzy interval arithmetic. Recall that if a certain criterion does not split, it is considered as its own copy within the set of subriteria, and the value of its weight with respect to the goal is preserved.

Step 7. Final assessments and synthesis. Several methods have been proposed to aggregate the decision maker's assessments. The most commonly used are the mean, median, max, min and mixed operators. The final alternative performance weights with respect to the overall goal are calculated by the summation of elements in the rows of the performance matrix (17) to obtain Eq. (19).

$$
F_{i}=\sum_{j=1}^{K} x_{i j} w_{j}, \quad i=1,2, \ldots, N
$$

To finally rank the alternatives, the prioritization of aggregated assessments is required. Since each $F_{i}$ is a triangular fuzzy number, it is necessary to apply the method of ranking triangular fuzzy numbers. There are several methods that can do this such as the centre of gravity method, the dominance measure method, the $\alpha$-cut with interval synthesis method and the total integral value method. The last one - the total integral value method [22], is considered to be a good choice for performing the task efficiently and, therefore, has been proposed within this methodology. For the given triangular fuzzy number $A=\left(a_{1}, a_{2}, a_{3}\right)$ the total integral value is defined as:

$$
I_{T}^{\lambda}(A)=\left[\lambda a_{3}+a_{2}+(1-\lambda) a_{1}\right] \cdot 2^{-1}, \quad \lambda \in[0,1]
$$

In Eq. (20), $\lambda$ represents an optimism index which expresses the decision maker's attitude towards risk. A larger value of $\lambda$ indicates a higher degree of optimism. In practical applications, values $0 ; 0,5$ and 1 are used respectively to represent the pessimistic, moderate and optimistic views of the decision maker. For given fuzzy numbers $A$ and $B$ it is said that if $I_{T}^{\lambda}(A)<I_{T}^{\lambda}(B)$, then $A<B$; if $I_{T}^{\lambda}(A)=I_{T}^{\lambda}(B)$ then $A=B$; and if $I_{T}^{\lambda}(A)>I_{T}^{\lambda}(B)$, then $A>B$.

The final ranking of alternatives means to adopt a certain level $\lambda$ of optimism of the decision-maker, then to apply Eq. (21) on fuzzy numbers Eq. (19), and finally to rank alternatives regarding obtained values for $I_{T}^{\lambda}(F)$, $i=1,2, \ldots, N$. The best alternative from the set is represented as

$$
f_{F_{i}}=\max \left(f_{F_{i}}\right), i=1,2, \ldots, A
$$

\section{Description of the study area}

The term integrated transport (IT) in the LBCP can be understood as the transportation of complete cargo units by means of different kinds or transport (means of transport of at least two types of vehicle) from the sender to the consignee of the load. Integrated transport cargo units are: pallets; containers; fully-equipped vehicles; road and rail vehicles; river reight barges; or only certain parts of vehicles (saddled trailers) and portable shipping containers.

A high degree of transformation and modernization of the logistics unit of the LBCP requires an appropriate new efficiency of the supply system of material resources in peacetime and in wartime. Improving the overall system of handling storage and transport is developed in two directions:

- The modernization and introduction of a modern integrated system of palletization and containerization

- Optimization of the existing capacity of classic transport systems.

The process of improving the system of integrated transport in the LBCP began in 2008. After formulation of the problem and producing the previous studies and programs of implementation in phases, the existing situation was recorded in the areas of packaging, storage, handling and transport of material resources for all technical carriers. On the basis of the above analysis and practical experiments, a subsystem of palletization was adopted. From that time on, practical work began on the use of appropriate technology in integrated transport.

When introducing integrated transport to the logistical organs of the LBCP the following elements of integrated transport were analyzed:

- Equipment and machinery, 
- Means of transport,

- Infrastructure,

- Organizational-formational development and

- Containerization.

In order to define the directions of further development of an integrated transport system, a SWOT analysis of the influence, i.e., the opportunities and threats surrounding the integrated transport system in the LBCP was carried out. After completing the SWOT analysis, the optimal strategies for developing an integrated transport system were selected. The choice of strategy was made using fuzzy AHP methods.

\section{Choice of development strategy for integrated transport using a FA'WOT model}

The first step of the SWOT analysis is to discover the strengths and weaknesses in the system of integrated transport. Then the opportunities and threats from the environment are identified, that is factors are identified that are independent of the Lafarge Beocin Cement Plant (Fig 1).

Opportunities in the environment are systematized on the basis of the responses to three questions:

1. What are the chances which the environment allows for the improvement of integrated transport in the LBCP?

2. What is it that members of the LBCP expect to see in a system of integrated transport, and which is not part of existing practice?
3. What specific measures and actions in environment can be directly applied to the LBCP?

The prerequisite for this step of analysis is knowledge of the state of integrated transport in environment, as well as scientific and technical trends in this field.

Threats in the environment are the key to the solution. It is necessary to ask the question: Which are the trends and circumstances in environment which harm the IT system, that is which hinder the improvements already achieved in the level of development of an integrated transport system in the LBCP? Threats from the environment can also be seen in the negative trends caused by the transition of the LBCP, drain of professional staff, and the absence of IT development strategy at higher levels, particularly at the state level, that is lack of financial resources. Based on the above, a SWOT analysis was carried out on the system of integrated transport (Tab. 1 and Tab. 2).

In the next step, the problem is converted into a hierarchical structure in order to transform the subfactors and alternative strategies into a state in which they can be measured by the AHP technique. The structure is shown in Fig. 1. The aim of "selecting the best strategy" is placed in the first level of the AHP model and the SWOT factors are in the second level. The SWOT subfactors in the third level include: four subfactors for the Strengths factor, five subfactors for the Weaknesses factor, four subfactors for the Opportunities factor, and five subfactors for the Threats factor. Four alternative strategies are placed in the last level of the model.

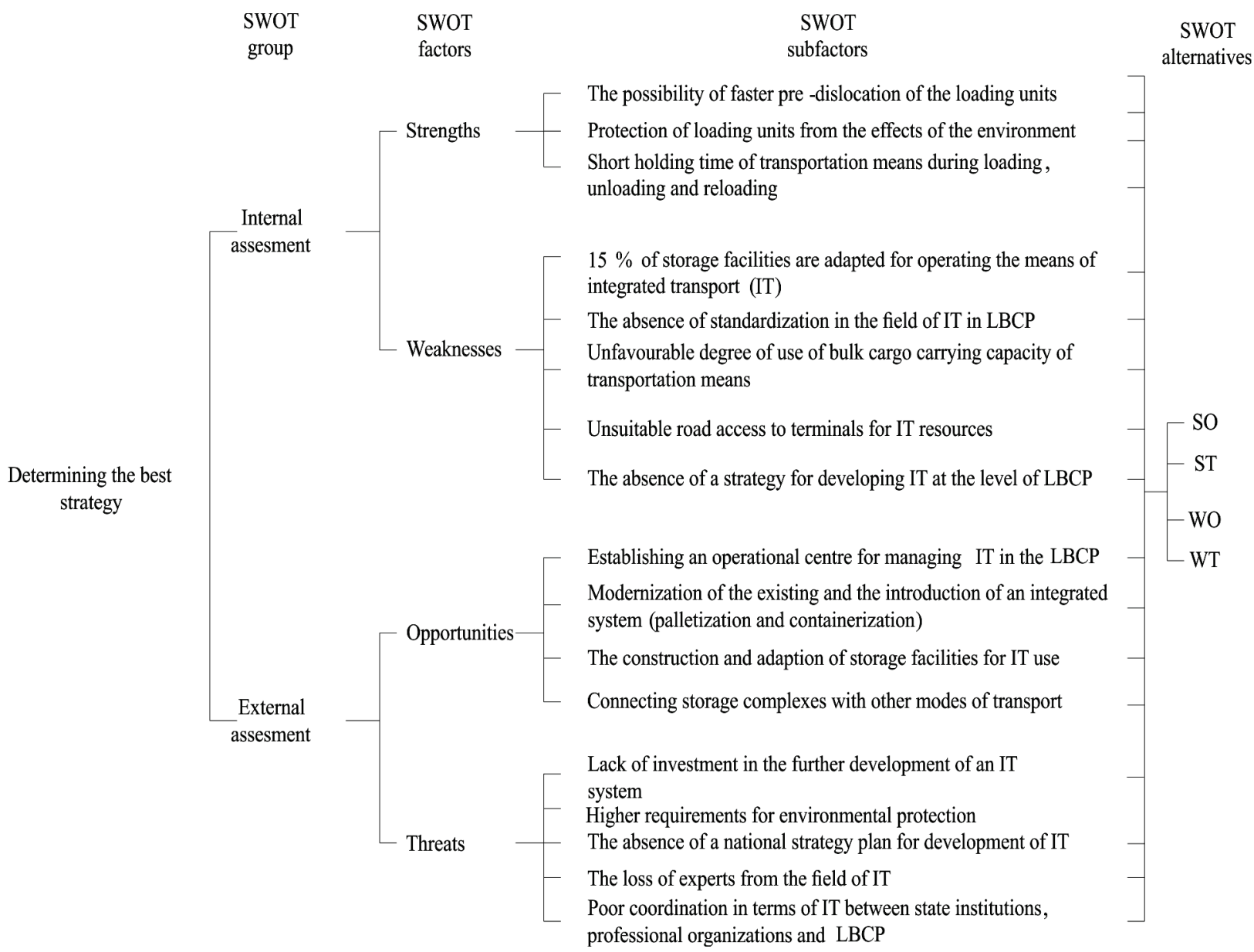

Figure 1 Decision hierarchy (AHP model for SWOT) 
Table 1 Factors and sub factors for the strategy selection

\begin{tabular}{|c|c|c|}
\hline & Factors & Subfactors \\
\hline \multirow{8}{*}{ Internal factors } & \multirow{3}{*}{ Strengths } & $\mathrm{S}_{1}$ : The possibility of faster pre-dislocation of the loading units \\
\hline & & $\mathrm{S}_{2}$ : Protection of loading units from the effects of the environment \\
\hline & & $\mathrm{S}_{3}$ : Short holding time of transportation means during loading, unloading and reloading \\
\hline & \multirow{5}{*}{ Weaknesses } & $\mathrm{W}_{1}: 15 \%$ of storage facilities are adapted for operating the means of integrated transport (IT) \\
\hline & & $\mathrm{W}_{2}$ : The absence of standardization in the field of IT in LBCP \\
\hline & & $\mathrm{W}_{3}$ : Unfavourable degree of use of bulk cargo carrying capacity of transportation means \\
\hline & & $\mathrm{W}_{4}$ : Unsuitable road access to terminals for IT resources \\
\hline & & $\mathrm{W}_{5}$ : The absence of a strategy for developing IT at the level of LBCP \\
\hline \multirow{9}{*}{ External factors } & \multirow{4}{*}{ Opportunities } & $\mathrm{O}_{1}$ : Establishing an operational centre for managing IT in the LBCP \\
\hline & & $\begin{array}{l}\mathrm{O}_{2} \text { : Modernization of the existing and the introduction of an integrated system (palletization and } \\
\text { containerization) }\end{array}$ \\
\hline & & $\mathrm{O}_{3}$ : The construction and adaption of storage facilities for IT use. \\
\hline & & $\mathrm{O}_{4}$ : Connecting storage complexes with other modes of transport \\
\hline & \multirow{5}{*}{ Threats } & $\mathrm{T}_{1}$ : Lack of investment in the further development of an IT system \\
\hline & & $\mathrm{T}_{2}:$ Higher requirements for environmental protection \\
\hline & & $\mathrm{T}_{3}$ : The absence of a national strategy plan for development of IT \\
\hline & & $\mathrm{T}_{4}$ : The loss of experts from the field of IT \\
\hline & & $\mathrm{T}_{5}$ : Poor coordination in terms of IT between state institutions, professional organizations and LBCP \\
\hline
\end{tabular}

Table 2 SWOT matrix

\begin{tabular}{|c|c|}
\hline \multicolumn{2}{|c|}{ Internal factors } \\
\hline Strengths $(S)$ & Weaknesses $(W)$ \\
\hline $\begin{array}{l}\mathrm{S}_{1} \text { : The possibility of faster pre- } \\
\text { dislocation of the loading units } \\
\mathrm{S}_{2} \text { : Protection of loading units from the } \\
\text { effects of the environment } \\
\mathrm{S}_{3} \text { : Short holding time of transportation } \\
\text { means during loading, unloading and } \\
\text { reloading }\end{array}$ & $\begin{array}{l}\mathrm{W}_{1}: 15 \% \text { of storage facilities are adapted for } \\
\text { operating the means of integrated transport } \\
\text { (IT) } \\
\mathrm{W}_{2}: \text { The absence of standardization in the } \\
\text { field of IT in LBCP } \\
\mathrm{W}_{3}: \text { Unfavourable degree of use of bulk } \\
\text { cargo carrying capacity of transportation } \\
\text { means } \\
\mathrm{W}_{4}: \text { Unsuitable road access to terminals for } \\
\text { IT resources }\end{array}$ \\
\hline SO strategies & WO strategies \\
\hline $\begin{array}{l}\text { 1. Construction of new and adaption of } \\
\text { existing storage facilities according to } \\
\text { modern methods. } \\
\text { 2. Facilitation of technical and repair } \\
\text { workshops for carrying out light and } \\
\text { medium repairs and the general overhaul } \\
\text { of IT means. }\end{array}$ & $\begin{array}{l}\text { 1.Standardization of both loading units and } \\
\text { transportation and reloading resources } \\
\text { 2. Developing an integrated transport } \\
\text { strategy in the LBCP } \\
\text { 3. Making an inventory of all types of } \\
\text { mechanized resources in storage and } \\
\text { determining the perspective for these existing } \\
\text { IT resources }\end{array}$ \\
\hline ST strategies & WT strategies \\
\hline $\begin{array}{l}\text { 1. Reduction of IT maintenance costs } \\
\text { through a choice of perspective } \\
\text { mechanization } \\
\text { 2. Increase in the safety of workers when } \\
\text { handling loads through constant education } \\
\text { of personnel } \\
\text { 3. The rationalization of the whole system } \\
\text { of goods distribution } \\
4 \text {. Adapt road access for the use of IT } \\
\text { resources. }\end{array}$ & $\begin{array}{l}\text { 1. Increase the exchange of experiences - of } \\
\text { good practice in the field of IT } \\
\text { 2. Increase investment in the further } \\
\text { development of IT } \\
\text { 3. State support in the procurement of IT } \\
\text { resources produced in Serbia }\end{array}$ \\
\hline
\end{tabular}

The aim of "selecting the best strategy" is placed in the first level of the AHP model and the SWOT factors are in the second level. The SWOT subfactors in the third level include: four subfactors for the Strengths factor, five subfactors for the Weaknesses factor, four subfactors for the Opportunities factor, and five subfactors for the
Threats factor. Four alternative strategies are placed in the last level of the model.

Pairwise comparison of the SWOT factors using Saaty's scale is made with respect to the goal. The comparison results are shown in Tab. 3. All pairwise 
comparisons in the application are performed by the expert team mentioned at the beginning of the study.

AHP is based on pairwise comparisons that are difficult and confusing to the respondents, as the participants (decision-makers) must compare all criteria, two by two, using AHP scales (1-9). Linguistically expressed preferences among the criteria have been used to create a judgment matrix A as given by Eq. (10).

$$
w_{C_{2}}=\left[\begin{array}{c}
w_{S} \\
w_{W} \\
w_{O} \\
w_{T}
\end{array}\right]=\left[\begin{array}{c}
(0,070 ; 0,140 ; 0,210) \\
(0,228 ; 0,455 ; 0,683) \\
(0,071 ; 0,141 ; 0,212) \\
(0,132 ; 0,263 ; 0,395)
\end{array}\right]
$$

Table 3 Pairwise comparison of SWOT factors

\begin{tabular}{|l|c|c|c|c|c|}
\hline & $\mathrm{S}$ & $\mathrm{W}$ & $\mathrm{O}$ & $\mathrm{T}$ & Weights \\
\hline S: Strengths & 1 & $3^{-1}$ & 1 & $2^{-1}$ & $(0,098 ; 0,140 ; 0,182)$ \\
\hline W: Weaknesses & & 1 & 3 & 2 & $(0,319 ; 0,455 ; 0,592)$ \\
\hline O: Opportunities & & & 1 & $2^{-1}$ & $(0,099 ; 0,141 ; 0,183)$ \\
\hline T: Threats & & & & 1 & $(0,184 ; 0,263 ; 0,342)$ \\
\hline I.R=0,00 & & & & & \\
\hline
\end{tabular}

The weighting vector $w$ of criteria matrix $A_{\text {SwOT }}$ (Tab. 3) was determined by applying Eq. (11). Each entry of this vector is the sum of elements in the related row of matrix $A_{\text {SWOT, }}$, divided by the sum of all its elements. For example:

$w_{S}=\frac{1+3^{-1}+1+2^{-1}}{1+3^{-1}+1+2^{-1}+1+3+2+1+2^{-1}+1}=(0,070 ; 0,140 ; 0,210)$
In the next step, local priorities of the SWOT subfactors are calculated. The pairwise comparison matrices are detailed in Tabs. 4, 5, 6, and 7. The I.R values are provided in the last row of the matrices and priority vectors obtained by analyzing the pairwise comparison matrices are shown next to the matrices.

Table 4 Pairwise comparison for Strengths

\begin{tabular}{ccccc}
\hline & $\mathrm{S}_{1}$ & $\mathrm{~S}_{2}$ & $\mathrm{~S}_{3}$ & Weights \\
\hline $\mathrm{S}_{1}$ & 1 & 2 & $2^{-1}$ & $(0,185 ; 0,264 ; 0,343)$ \\
$\mathrm{S}_{2}$ & & 1 & $4^{-1}$ & $(0,100 ; 0,143 ; 0,186)$ \\
$\mathrm{S}_{4}$ & & & 1 & $(0,355 ; 0,507 ; 0,659)$ \\
\hline $\mathrm{I} . \mathrm{R}=0.02$ & & & & \\
\hline
\end{tabular}

\begin{tabular}{lcccccc}
\multicolumn{7}{c}{ Table 5 Pairwise comparison for Weaknesses } \\
\hline & $\mathrm{W}_{1}$ & $\mathrm{~W}_{2}$ & $\mathrm{~W}_{3}$ & $\mathrm{~W}_{4}$ & $\mathrm{~W}_{5}$ & Weights \\
\hline $\mathrm{W}_{1}$ & 1 & $2^{-1}$ & 2 & $4^{-1}$ & & $(0,084 ; 0,120 ; 0,156)$ \\
$\mathrm{W}_{2}$ & 1 & 3 & $3^{-1}$ & 2 & $(0,147 ; 0,210 ; 0,273)$ \\
$\mathrm{W}_{3}$ & & 1 & $5^{-1}$ & $2^{-1}$ & $(0,049 ; 0,071 ; 0,092)$ \\
$\mathrm{W}_{4}$ & & & 1 & 4 & $(0,335 ; 0,479 ; 0,623)$ \\
$\mathrm{W}_{5}$ & & & & 1 & $(0,084 ; 0,120 ; 0,156)$ \\
\hline $\mathrm{I} \cdot \mathrm{R}=0.01$ & \multicolumn{7}{c}{} \\
\hline
\end{tabular}

\begin{tabular}{cccccc}
\multicolumn{5}{c}{ Table 6 Pairwise comparison for Opportunities } \\
\hline & $\mathrm{O}_{1}$ & $\mathrm{O}_{2}$ & $\mathrm{O}_{3}$ & $\mathrm{O}_{4}$ & Weights \\
\hline $\mathrm{O}_{1}$ & 1 & 4 & 2 & 5 & $(0,355 ; 0,507 ; 0,659)$ \\
$\mathrm{O}_{2}$ & & 1 & $2^{-1}$ & 2 & $(0,100 ; 0,143 ; 0,186)$ \\
$\mathrm{O}_{3}$ & & & 1 & 3 & $(0,185 ; 0,264 ; 0,343)$ \\
$\mathrm{O}_{4}$ & & & 1 & $(0,060 ; 0,086 ; 0,112)$ \\
\hline $\mathrm{I} \cdot \mathrm{R}=0.01$ & & \multicolumn{4}{c}{} \\
\hline
\end{tabular}

\begin{tabular}{|c|c|c|c|c|c|c|}
\hline & $\mathrm{T}_{1}$ & $\mathrm{~T}_{2}$ & $\mathrm{~T}_{3}$ & $\mathrm{~T}_{4}$ & $\mathrm{~T}_{5}$ & Weights \\
\hline $\mathrm{T}_{1}$ & 1 & 3 & 3 & 3 & 5 & $(0,293 ; 0,418 ; 0,543)$ \\
\hline $\mathrm{T}_{2}$ & & 1 & $2^{-1}$ & $3^{-1}$ & 2 & $(0,068 ; 0,097 ; 0,126)$ \\
\hline $\mathrm{T}_{3}$ & & & 1 & $2^{-1}$ & 3 & $(0,113 ; 0,161 ; 0,209)$ \\
\hline $\mathrm{T}_{4}$ & & & & 1 & 4 & $(0,183 ; 0,262 ; 0,341)$ \\
\hline $\mathrm{T}_{5}$ & & & & & 1 & $(0,043 ; 0,062 ; 0,081)$ \\
\hline
\end{tabular}

The judgment matrices (Eq. 12) for sub-criteria related to respective criteria were obtained. Related subcriteria weighting vectors were calculated as defined by Eq. (11). 


$$
\begin{aligned}
& w_{S_{i}}=\left[\begin{array}{l}
w_{S_{1}} \\
w_{S_{2}} \\
w_{S_{4}}
\end{array}\right]=\left[\begin{array}{l}
(0,185 ; 0,264 ; 0,343) \\
(0,100 ; 0,143 ; 0,186) \\
(0,355 ; 0,507 ; 0,659)
\end{array}\right] \\
& w_{W_{i}}=\left[\begin{array}{l}
w_{W_{1}} \\
w_{W_{2}} \\
w_{W_{3}} \\
w_{W_{4}} \\
w_{W_{5}}
\end{array}\right]=\left[\begin{array}{c}
(0,084 ; 0,120 ; 0,156) \\
(0,147 ; 0,210 ; 0,273) \\
(0,049 ; 0,071 ; 0,092) \\
(0,335 ; 0,479 ; 0,623) \\
(0,084 ; 0,120 ; 0,156)
\end{array}\right] \\
& w_{O_{i}}=\left[\begin{array}{c}
w_{O_{1}} \\
w_{O_{2}} \\
w_{O_{3}} \\
w_{O_{4}}
\end{array}\right]=\left[\begin{array}{c}
(0,355 ; 0,507 ; 0,659) \\
(0,100 ; 0,143 ; 0,186) \\
(0,185 ; 0,264 ; 0,343) \\
(0,060 ; 0,086 ; 0,112)
\end{array}\right] \\
& w_{T_{i}}=\left[\begin{array}{l}
w_{T_{1}} \\
w_{T_{2}} \\
w_{T_{3}} \\
w_{T_{4}} \\
w_{T_{5}}
\end{array}\right]=\left[\begin{array}{c}
(0,293 ; 0,418 ; 0,543) \\
(0,068 ; 0,097 ; 0,126) \\
(0,113 ; 0,161 ; 0,209) \\
(0,183 ; 0,262 ; 0,341) \\
(0,043 ; 0,062 ; 0,081)
\end{array}\right] \\
& w_{S}^{\prime}=w_{S_{i}} \cdot w_{S}=\left[\begin{array}{c}
w_{S_{1}} \cdot w_{S} \\
w_{S_{2}} \cdot w_{S} \\
w_{S_{3}} \cdot w_{S}
\end{array}\right]=\left[\begin{array}{l}
(0,098 ; 0,140 ; 0,182) \cdot(0,185 ; 0,264 ; 0,343) \\
(0,098 ; 0,140 ; 0,182) \cdot(0,100 ; 0,143 ; 0,186) \\
(0,098 ; 0,140 ; 0,182) \cdot(0,355 ; 0,507 ; 0,659)
\end{array}\right]=\left[\begin{array}{l}
(0,0181 ; 0,0369 ; 0,0624) \\
(0,0098 ; 0,0200 ; 0,0338) \\
(0,0348 ; 0,0709 ; 0,1199)
\end{array}\right] \text {. }
\end{aligned}
$$

\begin{tabular}{|c|c|c|c|c|}
\hline \\
\hline $\begin{array}{l}\text { SWOT } \\
\text { factors }\end{array}$ & Priority of factors & SWOT sub-factors & $\begin{array}{l}\text { Priority of the sub- } \\
\text { factors }\end{array}$ & Overall priority \\
\hline \multirow{3}{*}{ Strengths } & \multirow{3}{*}{$(0,098 ; 0,140 ; 0,182)$} & $\mathrm{S}_{1}:$ The possibility of faster pre-dislocation of the loading units & $(0,185 ; 0,264 ; 0,343)$ & $(0,018 ; 0,037 ; 0,062)$ \\
\hline & & $\begin{array}{l}\mathrm{S}_{2}: \text { Protection of loading units from the effects of the } \\
\text { environment }\end{array}$ & $(0,100 ; 0,143 ; 0,186)$ & $(0,098 ; 0,020 ; 0,035)$ \\
\hline & & $\begin{array}{l}\mathrm{S}_{3}: \text { Short holding time of transportation means during loading, } \\
\text { unloading and reloading }\end{array}$ & $(0,355 ; 0,507 ; 0,659)$ & $(0,035 ; 0,071 ; 0,119)$ \\
\hline \multirow{5}{*}{ Weaknesses } & \multirow{5}{*}{$(0,319 ; 0,455 ; 0,592)$} & $\begin{array}{l}\mathrm{W}_{1}: 15 \% \text { of storage facilities are adapted for operating the } \\
\text { means of integrated transport (IT) }\end{array}$ & $(0,084 ; 0,120 ; 0,156)$ & $(0,027 ; 0,055 ; 0,092)$ \\
\hline & & $\mathrm{W}_{2}:$ The absence of standardization in the field of IT in LBCP & $(0,147 ; 0,210 ; 0,273)$ & $(0,047 ; 0,096 ; 0,162)$ \\
\hline & & $\begin{array}{l}\mathrm{W}_{3} \text { : Unfavourable degree of use of bulk cargo carrying capacity } \\
\text { of transportation means }\end{array}$ & $(0,049 ; 0,071 ; 0,092)$ & $(0,016 ; 0,032 ; 0,054)$ \\
\hline & & $\mathrm{W}_{4}$ : Unsuitable road access to terminals for IT resources & $(0,335 ; 0,479 ; 0,623)$ & $(0,107 ; 0,218 ; 0,369)$ \\
\hline & & $\begin{array}{l}\mathrm{W}_{1}: 15 \% \text { of storage facilities are adapted for operating the } \\
\text { means of IT }\end{array}$ & $(0,084 ; 0,120 ; 0,156)$ & $(0,027 ; 0,055 ; 0,092)$ \\
\hline \multirow{4}{*}{ Opportunities } & \multirow{4}{*}{$(0,099 ; 0,141 ; 0,183)$} & $\begin{array}{l}\mathrm{O}_{1}: \text { Establishing an operational centre for managing IT in the } \\
\mathrm{LBCP}\end{array}$ & $(0,355 ; 0,507 ; 0,659)$ & $(0,035 ; 0,071 ; 0,121)$ \\
\hline & & $\begin{array}{l}\mathrm{O}_{2}: \text { Modernization of the existing and the introduction of an } \\
\text { integrated system (palletisation and containerization) }\end{array}$ & $(0,100 ; 0,143 ; 0,186)$ & $(0,009 ; 0,020 ; 0,034)$ \\
\hline & & $\begin{array}{l}\mathrm{O}_{3}: \text { The construction and adaption of storage facilities for IT } \\
\text { use }\end{array}$ & $(0,185 ; 0,264 ; 0,343)$ & $(0,018 ; 0,037 ; 0,063)$ \\
\hline & & $\begin{array}{l}\mathrm{O}_{4}: \text { Connecting storage complexes with other modes of } \\
\text { transport }\end{array}$ & $(0,060 ; 0,086 ; 0,112)$ & $(0,006 ; 0,012 ; 0,020)$ \\
\hline \multirow{5}{*}{ Threats } & \multirow{5}{*}{$(0,184 ; 0,263 ; 0,342)$} & $\begin{array}{l}\mathrm{T}_{1}: \text { Lack of investment in the further development of an IT } \\
\text { system }\end{array}$ & $(0,293 ; 0,418 ; 0,543)$ & $(0,054 ; 0,109 ; 0,185)$ \\
\hline & & $\mathrm{T}_{2}:$ Higher requirements for environmental protection & $(0,068 ; 0,097 ; 0,126)$ & $(0,012 ; 0,026 ; 0,043)$ \\
\hline & & $\mathrm{T}_{3}:$ The absence of a national strategy plan for development of & $(0,113 ; 0,161 ; 0,209)$ & $(0,021 ; 0,042 ; 0,071)$ \\
\hline & & $\mathrm{T}_{4}:$ The loss of experts from the field of IT & $(0,183 ; 0,262 ; 0,341)$ & $(0,034 ; 0,069 ; 0,117)$ \\
\hline & & $\begin{array}{l}\mathrm{T}_{5}: \text { Poor coordination in terms of IT between state institutions, } \\
\text { professional organizations and LBCP }\end{array}$ & $(0,043 ; 0,062 ; 0,081)$ & $(0,008 ; 0,016 ; 0,028)$ \\
\hline
\end{tabular}

Table 8 Overall priority of the SWOT subfactors

The computations are presented in Tab. 8. The assessment of alternatives has been performed using relations 14,15 and 16 .

The final alternative performance weights, with respect to the overall goal, have been calculated by Eq. (19) as:

$$
W_{\text {alternatives }}=\left[\begin{array}{c}
S O \\
S T \\
W O \\
W T
\end{array}\right]=\left[\begin{array}{l}
(0,126 ; 0,180 ; 0,234) \\
(0,121 ; 0,173 ; 0,225) \\
(0,230 ; 0,329 ; 0,428) \\
(0,222 ; 0,317 ; 0,412)
\end{array}\right] \text {. }
$$


For the typical values of $\lambda$ that express the decisionmaker's attitude toward risk, the final ranking of alternatives is obtained by applying Eq. (20). The normalized values presented in Tab. 9 show that Alternative 2 is the best. It is followed by Alternative 4, Alternative 3 and Alternative 1 respectively, regardless of the decision-maker's level of optimism.

Table 9 Final ranking of alternatives

\begin{tabular}{|c|c|c|c|c|}
\hline \multirow{2}{*}{$\begin{array}{c}\text { Decision } \\
\text { alternative }\end{array}$} & \multicolumn{3}{|c|}{ Index of optimism } & \multirow{2}{*}{ Final rank } \\
\cline { 2 - 5 } & $\lambda=0,2$ (pessimistic) & $\lambda=0,7$ (moderate) & $\lambda=1,0$ (optimistic) & 0,207 \\
\hline$S O$ & 0,164 & 0,191 & 0,199 & 4 \\
\hline$S T$ & 0,157 & 0,183 & 0,379 & 1 \\
\hline$W O$ & 0,299 & 0,349 & 0,365 & 2 \\
\hline$W T$ & 0,289 & 0,336 & \\
\hline
\end{tabular}

By using the centre of gravity method (Eq. 20) to defuzzify the $W_{\text {alternatives }}$ values given above, the final weights of alternatives obtained after normalization were: 0,187 (Alternative 1 - SO), 0,180 (Alternative 2 - ST), 0,342 (Alternative 3 - WO) and 0,330 (Alternative 4 WT). Obviously, the final ranking is equal to the previous one.

\section{Discussion and conclusion}

In the SWOT analysis, strategic alternatives are selected in view of the strengths, weaknesses, threats, and opportunities as determined through internal and external environment analysis. The AHP enables decision makers to assign a relative priority to each factor through pairwise comparison. Used in combination with AHP, the SWOT approach can provide a quantitative measure of importance of each factor on decision-making.

In this study, the SWOT-AHP method has been used to prioritize the alternative strategies and select the best strategy for the choice of strategy for developing integrated transport. First, an environment analysis was performed and the SWOT subfactors which have significant effect on the choice of strategy for the development of integrated transport were identified. The factors from the SWOT analysis and the alternative strategies based on these factors were transformed into an AHP model. The first four levels of the AHP model consist of a goal (choosing the best strategy), four SWOT factors, 18 SWOT subfactors, and four alternative strategies groups, respectively. The importance degrees of the alternative strategies and the overall priorities of the alternative strategies were calculated. According to the AHP analysis, alternative strategies are ordered as WO $\mathrm{WT}-\mathrm{SO}-\mathrm{ST}$. The results indicate that WO is the best strategy for developing integrated transport.

On the basis of the SWOT analysis carried out, the following aims were introduced, the implementation of which is necessary in order to improve the system of integrated transport in the LBCP:

- To standardize transportation, loading resources and software in the field of IT, and transport in general;

- To secure a qualified personnel structure for working with IT. This needs to be done with technical support in order to provide the conditions and opportunities for training, not only for those operating machinery in storage facilities, but also for administrative staff;

- To make an inventory of all types of mechanized resources in storage and determine the perspective for the existing IT resources, defining which resources and equipment should be kept under operative records as well as introducing automated monitoring;

- The construction of new and adaption of existing storage capacity according to modern methods and tactical - technical requirements;

- To define a place in the IT system for a container subsystem and define its reliability and boundaries with the palletization subsystem and other transport systems. Based on this and the flow of material resources, to define norms for equipping all elements of a container system;

- To propose an organizational solution for the functioning of a container system in the logistical security of the LBCP in the unique transportation system of the Republic of Serbia. For this, it is necessary to define the required financial investments and the effects that are achieved on the basis of the above costs.

Finally, we can conclude that the results of the research indicate the need for investment in the modernization of IT resources and storage capacities in the LBCP. During modernization of the machinery for integrated transport, particular attention should be paid to existing resources for integrated transport which could possibly be modified and adapted to meet the requirements of logistics support. In the coming period it is necessary to eliminate the weaknesses of DHP 2000 cranes, eliminate the weaknesses of forklift trucks for fuel in confined areas, eliminate the weaknesses of stacking forklift trucks and provide technical workshops with new equipment for charging batteries. In addition, it is necessary to adapt the existing means of transport for the transportation and stabilization of handling units.

\section{Acknowledgements}

The work reported in this paper is a part of the investigation within the research project TR 36017 supported by the Ministry for Science and Technology, Republic of Serbia. This support is gratefully acknowledged.

\section{References}

[1] Bana, E.; Costa, C. A.; Vincke, P Multiple Criteria Decision Aid, Springer Verlag, Berlin-Heidelberg, (1990), pp. 3-14. DOI: 10.1007/978-3-642-75935-2_1

[2] Wasike, C. B.; Magothe, T. M.; Kahi, A. K.; Peters, K. J. Factors that influence the efficiency of beef and dairy cattle recording system in Kenya: a SWOT - AHP analysis. // 
Tropical Animal Health and Production. 43, 1(2010), pp. 141-152. DOI: 10.1007/s11250-010-9666-3

[3] Taleai, M.; Mansourian, M.; Sharifi, A. Surveying general prospects and challenges of GIS implementation in developing countries: a SWOT - AHP approach. // Journal of Geogrphycal Systems. 11, 3 (2009), pp. 291-310. DOl: 10.1007/s10109-009-0089-5

[4] Dyson, R. G. Strategic development and SWOT analysis at the University of Warwick. // European Journal of Operations Research, 152 (2004), pp. 631-640. DOl: 10.1016/S0377-2217(03)00062-6

[5] Pamucar, D.; Cirovic, G.; Sekulovic, D.; Ilic, A. A new fuzzy mathematical model for multi criteria decision making: An application of fuzzy mathematical model in an SWOT analysis. // Scientific Research and Essays. 6, 25(2011), pp. 5374-5386.

[6] Yüksel, I.; Dagdeviren, M. Using the analytic network process (ANP) in a SWOT analysis - A case study for a textile firm. // Information Sciences. 177, 16(2007), pp. 3364-3382. DOI: 10.1016/j.ins.2007.01.001

[7] Djorovic, B.; Pamucar, D.; Dimitrijevic, N. Application of fuzzy logic and fuzzy sets for quantification of input and output parametres in DEA analysis. // Metalurgia international. 17, 5(2012), pp. 78-86.

[8] Kajanus, M.; Kangas, J.; Kurttila, M. The use of value focused thinking and the A'WOT hybrid method in tourism management. // Tourism Management. 25, (2004) pp. 499506. DOI: $10.1016 / \mathrm{S} 0261-5177(03) 00120-1$

[9] Hill, T.; Westbrook, R. SWOT analysis: it's time for a product recall. // Long Range Plann. 30, 1(1997), pp. 46-52. DOI: 10.1016/S0024-6301(96)00095-7

[10] Wheelen, T. L.; Hunger, J. D. Strategic management and business policy. Addison -Wesley, Reading, MA. 1995.

[11] Kurttila, M.; Pesonen, M.; Kangas, J.; Kajanus, M. Utilizing AHP in SWOT analysis - a hybrid method and its application to a forestcertification case. // Forest Policy and Economics. 1, 1(2000), pp. 41-52. DOI: 10.1016/S13899341(99)00004-0

[12] Chang, H. H.; Huang, W. C. Application of a quantification SWOT analytical method. // Mathematical Computation Modeling. 43, 1(2006), pp. 158-169. DOl: 10.1016/j.mcm.2005.08.016

[13] Saaty, T. L., Vargas, L. G. Models, methods, concepts and applications of the analytic hierarchy process. Kluwer, Academic Publishers, Boston, MA, 2001. DOI: 10.1007/9781-4615-1665-1

[14] Ananda, J.; Herath G. The use of analytic hierarchy process to incorporate stakeholder preferences into regional forest planning. // Forest Policy and Economics. 5, 1(2003), pp. 13-26. DOI: 10.1016/S1389-9341(02)00043-6

[15] Pesonen, M.; Kurttila, M.; Kangas, J.; Kajanus, M.; Heinonen, P. Assessing the priorities using A'WOT among resource management strategies at the Finish Forest and Park. // Service for Science. 47, 4(2001), pp. 534-541.

[16] Ho, W. Integrated analytic hierarchy process and its application - a literature review. // European Journal of Operations Research. 186, 1(2008), pp. 211-228. DOI: 10.1016/j.ejor.2007.01.004

[17] Leskinen, L. A.; Leskinen, P.; Kurttila, M.; Kangas, J.; Kajanus, M. Adapting modern strategic decision support tools in the participatory strategy process - A case study of a forest research station. // Forest Policy and Economics. 8, 3(2004), pp. 267-278. DOI: 10.1016/j.forpol.2004.06.007

[18] Masozera, M. K.; Alavalapati, J. R. R.; Jacobson, S. K.; Shresta, R. K. Assessing the suitability of community based management for the Nyungwe Forest Reserve. // Forest Policy and Economics. 8, 2(2006), pp. 206-216. DOl: 10.1016/j.forpol.2004.08.001
[19] Stewart, R. A.; Mohamed, S.; Daet, R. Strategic implementation of IT/IS projects in construction: a case study. // Automation in Construction. 11, 6(2002), pp. 681694. DOI: 10.1016/S0926-5805(02)00009-2

[20] Shrestha, R. K.; Alavalapati, J. R. R.; Kalmbacher, R. S. Exploring the potential for silvopasture adoption in south central Florida: An application of SWOT - AHP method. // Agricultural Systems. 81 (2004), pp. 185-199. DOl: 10.1016/j.agsy.2003.09.004

[21] Weihrich, H. The TOWS matrix - a tool for situation analysis. // Long Range Planning. 15, 2(1982), pp. 54-66. DOI: 10.1016/0024-6301(82)90120-0

[22] Sajfert, Z.; Besic, C.; Damnjanovic, A.; Musicki, S.; Popovic, B. The Research of Lighting's Influence on the Psychological State of Employees in Working Environment. // Healthmed. 6, 2(2012), pp. 352-359.

[23] Pamucar, D.; Djorovic, B.; Bozanic, D.; Cirovic, G. Modification of the dynamic scale of marks in analytic hierarchy process (AHP) and analytic network approach (ANP) through application of fuzzy approach. // Scientific Research and Essays. 7(2012), pp. 24-37.

\section{Authors' addresses}

Dragan Pamučar, Ph.D. Assistant professor University of Defense, Department of logistic, Pavla Jurisica Sturma 33, 11000 Beograd, Serbia E-mail: draganpamucar@gmail.com

\section{Goran Cirović, Ph.D. Full professor}

The Belgrade University College of Civil Engineering and Geodesy, Belgrade, Serbia,

Hajduk Stankova br. 2, 11000 Beograd, Serbia

E-mail: cirovic@sezampro.rs

Dragoljub Sekulović, Ph.D. Associate professor

University of Defense, Department of Geodesy, Pavla Jurisica Sturma 33, 11000 Beograd, Serbia E-mail: sekulovicdr@yahoo.co.uk 